\title{
Wybrane aspekty identyfikacji zakłóceń procesu spawania łukowego MIG/MAG
}

\author{
Selected aspects of welding defects identification \\ in MIG/MAG arc welding
}

\section{Streszczenie}

Postępująca automatyzacja i robotyzacja procesów produkcyjnych wymaga nowych, równie wydajnych i zautomatyzowanych metod kontroli jakości produktu. W przypadku spawania łukowego, oprócz prowadzonego w tym celu pomiaru i biernej rejestracji parametrów procesu, niektóre systemy monitorujące mogą sprawować funkcje automatycznego nadzoru połączonego $\mathrm{np}$. z sygnalizacją przekroczeń, przewidywaniem niezgodności spawalniczych, a nawet ingerencją w pracę maszyny i proces spawalniczy. W artykule przedstawiono wyniki nowych badań nad automatyczną identyfikacją zakłóceń procesu spawania łukowego MIG/MAG.

Słowa kluczowe: pomiary; monitorowanie; spawanie łukowe

\begin{abstract}
Progressing automation and robotization of industry processes call for increasingly efficient and automated means of product quality control. In the case of industrial arc welding, these new monitoring systems cannot only measure and save process parameters, but can also actively use these measurements to control the process by warning when parameters exceed preset thresholds, dynamically interrupting the welding process, and even predicting defects in the final product. This article presents results for a newly developed method of automatic identification of welding (defects, imperfections) in MIG/MAG processes.
\end{abstract}

Keywords: measurements; monitoring; arc welding

\section{Wprowadzenie}

Monitorowanie procesów produkcyjnych, także spawalniczych, to zespół działań oraz niezbędnych środków technicznych służących do obserwacji (poprzez pomiar w czasie rzeczywistym) wybranych parametrów technologicznych, ich rejestracji (zapamiętywania), filtrowania (przetwarzania, m.in. w celu czytelnej wizualizacji), a niekiedy także interpretacji, np. odniesienia do nałożonych progów $[2 \div 4,9]$. Zasadność choćby uproszczonego monitorowania wynika nie tylko z wymagań narzuconych warunkami umowy produkcyjnej i odpowiednich norm jakościowych, ale może ułatwiać późniejsze naprawy i modernizacje, upraszczać spory gwarancyjne itp. [2,8].

W procesach łukowych MIG/MAG monitorowanie dotyczyć będzie oczywiście prądu spawania, napięcia łuku i prędkości podawania drutu elektrodowego, a często także wydatku (przepływu) gazu osłonowego. Próbuje się również wykorzystywać pomiary wartości nieelektrycznych powiązanych z procesem, takich jak dźwięk emitowany przez łuk [6]. Pozostałe, w tym nastawy źródeł synergicznych, takie jak średnica i gatunek drutu elektrodowego, rodzaj lub skład gazu osłonowego czy korekty specyficzne dla odmiany procesu i typu źródła zasilającego łuk mogą zostać zapisane jako parametry uzupełniające, stałe dla całego cyklu. Parametry związane z ruchem elektrody, w tym prędkość spawania (informacja konieczna przy kontroli energii liniowej spawania), a nawet jej dokładna trajektoria i orientacja, mogą być monitorowane przede wszystkim podczas spawania zautomatyzowanego i zrobotyzowanego, $\mathrm{np}$. w oparciu o sygnały przekazywane z układu sterującego maszyny manipulacyjnej. W innych przypadkach, w tym podczas spawania ręcznego, informacje o ruchu elektrody mogą zostać określone pośrednio, poprzez skonfrontowanie długości spoiny z czasem jej wykonania.

Niezależnie od stopnia uszczegółowienia rejestracji oraz konfiguracji sprzętowej (systemy uniwersalne lub dedykowane - rys. 1), monitorowanie spawania łukowego może obejmować [2 $\div 4]$ :

- rejestrację wybranych parametrów technologicznych w funkcji czasu;

- szacowanie wprowadzanego ciepła (energii liniowej), kosztów, zużycia materiałów itp.;

- monitorowanie pracy spawacza lub operatora (w tym statystyka czasu pracy);

- monitorowanie stanu maszyn (w tym błędów i awarii);

Dr inż. Paweł Cegielski, inż. Łukasz Bugyi - Politechnika Warszawska.

Autor korespondencyjny/Corresponding author. pcegiels@wip.pw.edu.pl 
- opcjonalnie, kontrolę jakości procesu, poprzez analizę zarejestrowanych parametrów:

- odchyłek parametrów od założonych progów (tzw. progowanie),

- innych anomalii parametrów spawania,

- alarmowanie o przekroczeniach,

- korygowanie parametrów, reakcje awaryjne (np. funkcje wbudowane w niektóre spawalnicze urządzenia zasilające),

- monitorowanie i rejestracja do celów badawczych.

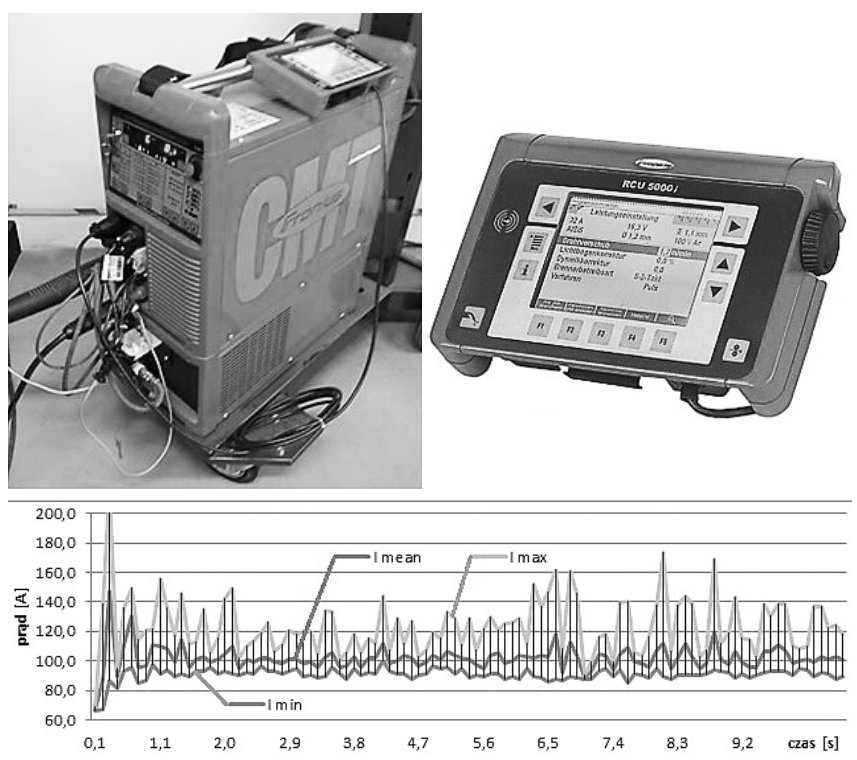

Rys. 1. Dedykowana przystawka monitorująca Fronius RCU 5000i oraz przykładowa rejestracja prądu spawania

Fig. 1. Specialized welding monitor unit Fronius RCU 5000i and an example of recorded welding current

Miniaturyzacja coraz wydajniejszych komputerów, stały postęp w dziedzinie elektroniki i technik pomiarowych sprzyja również rozwojowi systemów monitorowania. Możliwa jest dokładna rejestracja coraz większej liczby parametrów oraz ich zaawansowane filtrowanie i przetwarzanie. Daje to nadzieję na coraz skuteczniejsze rozpoznawanie zakłóceń towarzyszących spawaniu, w tym ich identyfikację i ocenę skutków dla jakości procesu. W takim kierunku zmierzały także badania omówione w dalszej części artykułu.

\section{Idea identyfikacji zakłóceń procesu spawania łukowego}

Dotychczasowe badania prowadzone w Zakładzie Inżynierii Spajania Politechniki Warszawskiej nad identyfikacją zakłóceń i możliwych w ich następstwie niezgodności spawalniczych koncentrowały się na szczegółowej i pracochłonnej analizie impulsów prądu spawania i napięcia łuku. Polegały one na m.in. odseparowywaniu składowych przebiegu prądu spawania (i napięcia łuku) w fazie zwarcia (o ile zachodziło) i jarzenia się łuku oraz wyznaczeniu mocy dynamicznej i rezystancji dynamicznej w obwodzie spawania, również z wyodrębnieniem składowych w stanie zwarcia (o ile zachodziło) i jarzenia się łuku. Dalej, odseparowane przebiegi filtrowano według autorskiej koncepcji, a każdy z nich porównywano z wynikami próby wzorcowej i odnoszono do opracowanego katalogu wskaźników identyfikacyjnych. Mankamentem metody była wysoka pracochłonność obliczeniowa oraz duża liczba wskaźników, indywidualnie wyznaczanych dla każdej odmiany spawania MIG/MAG $[5,7]$.
Z drugiej strony, nawet najprostsze systemy gromadzące uśredniony zapis prądu spawania i napięcia łuku (jak na rys. 1) pozwalają na wykrywanie niektórych zakłóceń w przebiegu spawania, o ile towarzyszy im wyraźne, długotrwałe i wykraczające ponad ustalony przebieg, zaburzenie [2]. Nie ma tu jednak możliwości identyfikacji rodzaju zakłócenia.

Zaproponowana, nowa metodyka analizy wykorzystuje periodyczny, impulsowy charakter sygnału prądowo-napięciowego towarzyszącego spawaniu łukowemu (tu MIG/MAG). Owa pulsacja może mieć różnorodny charakter - zostać wymuszona zadanym przebiegiem zasilającym (np. przy spawaniu prądem pulsującym), wynikać z procesów fizycznych zachodzących podczas samoistnego tworzenia się i przechodzenia kropli ciekłego metalu do jeziorka lub być mieszaniną obydwu sposobów. Niezależnie od wariantu, wszelkie zaburzenia $\mathrm{w}$ przebiegu spawania powinny spowodować odstępstwa od ustalonego kształtu prądu spawania i napięcia łuku, nawet jeśli źródło zasilające łuk pracuje pod nadzorem sprawnego sterownika komputerowego, co potwierdziły wcześniejsze badania [5,7]. Odrębnym zakłóceniem mogą być tętnienia wewnętrznego przetwarzania inwertora źródła zasilającego, które jednak mogą zostać poddane odpowiedniej filtracji.

Metodyka opisana w artykule polega na wyliczaniu współczynnika odchylenia kształtu pomiędzy impulsem wzorcowym (prądu spawania) oraz impulsem występującym w badanym, rzeczywistym sygnale. Na podstawie rozkładu wartości współczynnika odchylenia dla wszystkich impulsów w zarejestrowanym przebiegu można wnioskować o stopniu jego zniekształcenia, a więc o poprawności spawania, a może nawet o ewentualnej przyczynie zakłócenia i miejscu jego wystąpienia (w dziedzinie czasu).

\section{Sprzęt i metodyka badań}

Celem eksperymentów była weryfikacja opracowanej metodyki monitorowania podczas prób zrobotyzowanego napawania różnymi odmianami metody MAG w warunkach niezakłóconego procesu (próby odniesienia) i z celowo wprowadzonymi zaburzeniami. Do badań wykorzystano zmodernizowany robot spawalniczy IRp-6 (ZAP - Robotyka) oraz sterowane cyfrowo źródło inwertorowe TPS 2700CMT firmy Fronius (rys. 2), pozwalające na spawanie różnymi odmianami metody MAG ( $w$ badaniach wykorzystano tryby MAG Puls - spawanie prądem pulsującym i MAG CMT - odmiana niskoenergetyczna z pulsacją posuwu drutu elektrodowego).

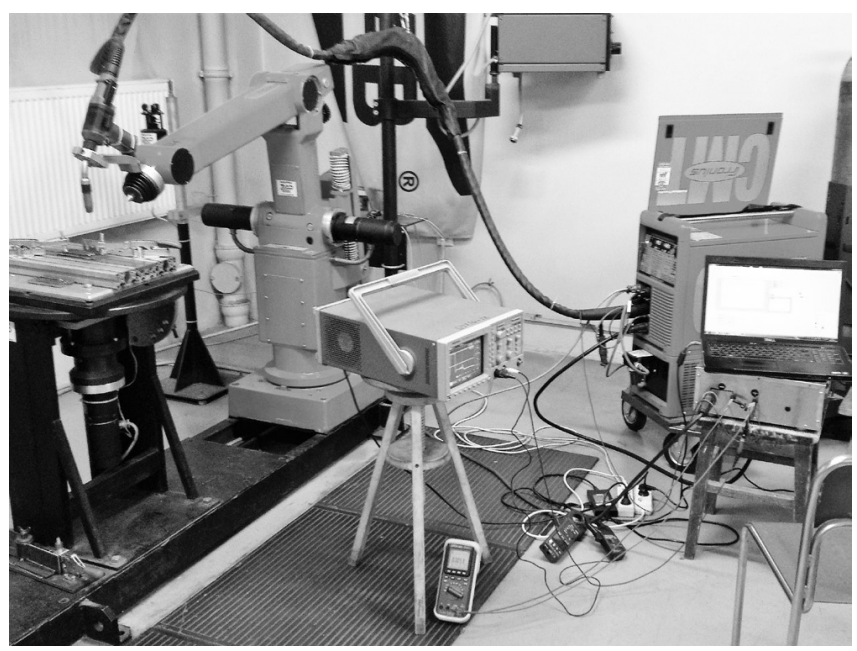

Rys. 2. Stanowisko laboratoryjne podczas badań

Fig. 2. Laboratory installation during tests 
Napawano na powierzchni płytek ze stali konstrukcyjnej

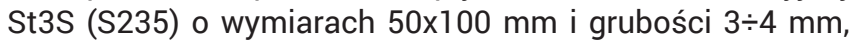
metalicznie czystych i odtłuszczonych. Wykorzystano drut elektrodowy G3SI1 firmy ESAB o średnicy 0,8 mm oraz gaz osłonowy $\mathrm{M} 21$ (80\% $\mathrm{Ar}$ i $20 \% \mathrm{CO}_{2}$ ).

Dla wybranej odmiany spawania MAG (MAG Puls lub CMT), przyjętego rodzaju mieszanki osłonowej, materiału i średnicy drutu elektrodowego, zadawano prąd 90 i 120 A przy stałej prędkości spawania $7,5 \mathrm{~mm} / \mathrm{s}$.

Dla każdej odmiany metody MAG w pierwszej kolejności wykonywano próby wzorcowe, bez zakłóceń procesu napawania. Podczas kolejnych, proces prowadzono w warunkach kontrolowanych, symulowanych zakłóceń, w tym m.in.:

- napawano przy wykorzystaniu wyeksploatowanej tulejki prądowej (nominalnie do drutu elektrodowego ø 0,8 mm), z nieosiowym śladem wytarcia (rys. 3a);

- redukowano gaz osłonowy - częściowo bądź całkowicie odcinano dopływ gazu osłonowego;

- rejestrowano przejście łuku z metalicznie czystej powierzchni na powierzchnię zanieczyszczoną piaskiem stosowanym do piaskowania (rys. 3b);

- napawano poprzecznie do uprzednio nałożonych napoin. Zaproponowane przypadki zakłóceń odzwierciedlają różne problemy towarzyszące pracom spawalniczym, zwłaszcza w warunkach ograniczonej kontroli przez człowieka, podczas mechanizacji i automatyzacji. Zalegający piasek może dotyczyć procesów montażowych i remontowych prowadzonych w warunkach polowych, także po piaskowaniu. Redukcja, a nawet zanik osłony gazowej może wynikać nie tylko $z$ łatwego do monitorowania braku lub źle ustawionego przepływy gazu, ale być powodowany czynnikami zewnętrznymi, takimi jak przeciągi, specyficzne ukształtowanie złączy itp. Nadmiernie zużyta, wyeksploatowana tulejka prądowa jest przyczyną iskrzenia i strat energii doprowadzanej do łuku, powodując wzrost rozprysku, mniejsze wtopienie, przyklejenia itp. Dodatkowo, w procesach ze zmechanizowanym prowadzeniem uchwytu elektrodowego może powodować niekontrolowane odchylanie drutu elektrodowego (a więc i łuku) od osi narzędzia.

W roli podstawowego sprzętu pomiarowego wykorzystano będącą własnym opracowaniem kasetę pomiarową KWR1 (rys. 4), opartą na wbudowanej karcie DAQ (model USB 6351 firmy National Instruments) oraz hallotronowych przetwornikach do pomiaru prądu (LEM LF 505-S, dokładność w $25^{\circ} \mathrm{C}$ równa $\pm 0,5 \%$, czas odpowiedzi poniżej $0,1 \mu \mathrm{s}$ ) i napięcia (LEM CV $3-100$, dokładność w $25^{\circ} \mathrm{C}$ równa $\pm 0,2 \%$, czas odpowiedzi 0,4 $\mu$ s).

Uzupełniające, weryfikujące wyposażenie pomiarowe stanowiły przyrządy ręczne (klasy laboratoryjnej i technicznej), oscyloskopy itp. Prąd spawania mierzono na przewodzie

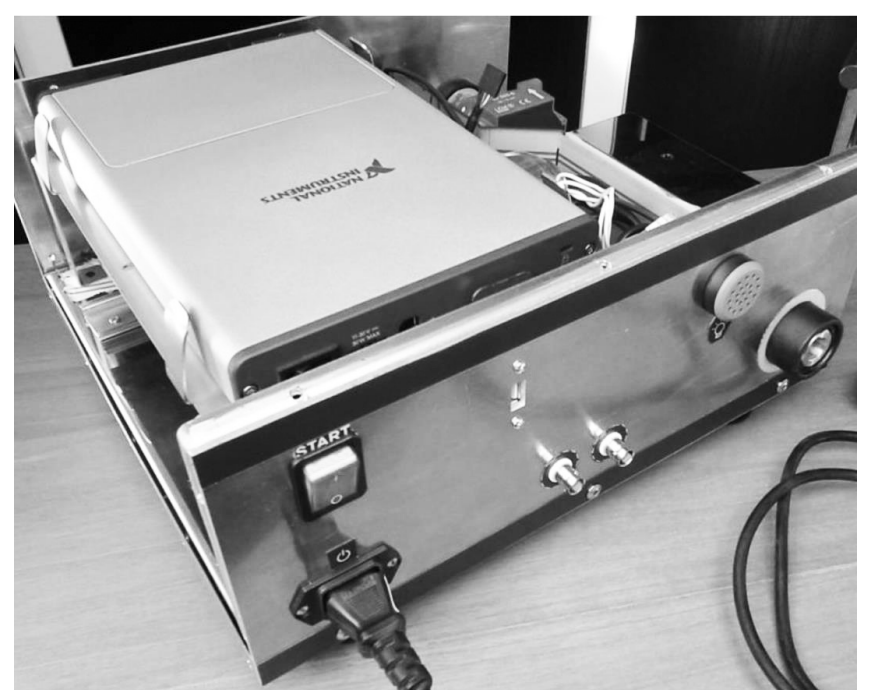

Rys. 4. Kaseta pomiarowa KWR1 (widok wewnętrzny)

Fig. 4. Measuring unit KWR-1 (internal view)

masowym. Napięcie łuku kontrolowano pomiędzy podajnikiem drutu elektrodowego a miejscem podłączenia masy do stołu spawalniczego.

Rejestrację, a przede wszystkim analizę danych prowadzono przy wykorzystaniu tzw. wirtualnego przyrządu pomiarowego [1] opartego na wspomnianej kasecie pomiarowej z podłączonym komputerem PC i specjalnie w tym celu napisanej aplikacji pomiarowo-sterującej (LabView, licencja badawcza), realizującej omówioną wcześniej ideę automatycznej identyfikacji zakłóceń procesu spawania łukowego. Rejestracja i przetwarzanie przebiegały etapowo. Początkowo, z rejestrowanego sygnału usuwano części przebiegu, które dotyczyły bezczynności źródła spawalniczego (tuż przed i zaraz po procesie) oraz związane z początkową fazą zajarzania łuku, najczęściej znacznie zniekształconą (rys. 5).

Drugi etap przetwarzania sygnału miał na celu określenie poprawności procesu spawania (napawania) oraz identyfikację potencjalnych przyczyn niepoprawności. Zgodnie z przyjętą ideą, jako wielkość określającą impuls przyjęto współczynnik odchylenia kształtu impulsu badanego w stosunku do wcześniej zarejestrowanego wzorca. W pierwszej kolejności algorytm identyfikował wszystkie obecne w sygnale impulsy prądowe, a następnie przyporządkowywał każdemu procentową wartość odchylenia od impulsu wzorcowego (rys. 6 i 7). Na tym etapie aplikacji, impulsy wzorcowe (dla metod MAG Puls oraz CMT) wybierane były ręcznie z przebiegów niezakłóconych, natomiast pozostała analiza przebiega samoczynnie.
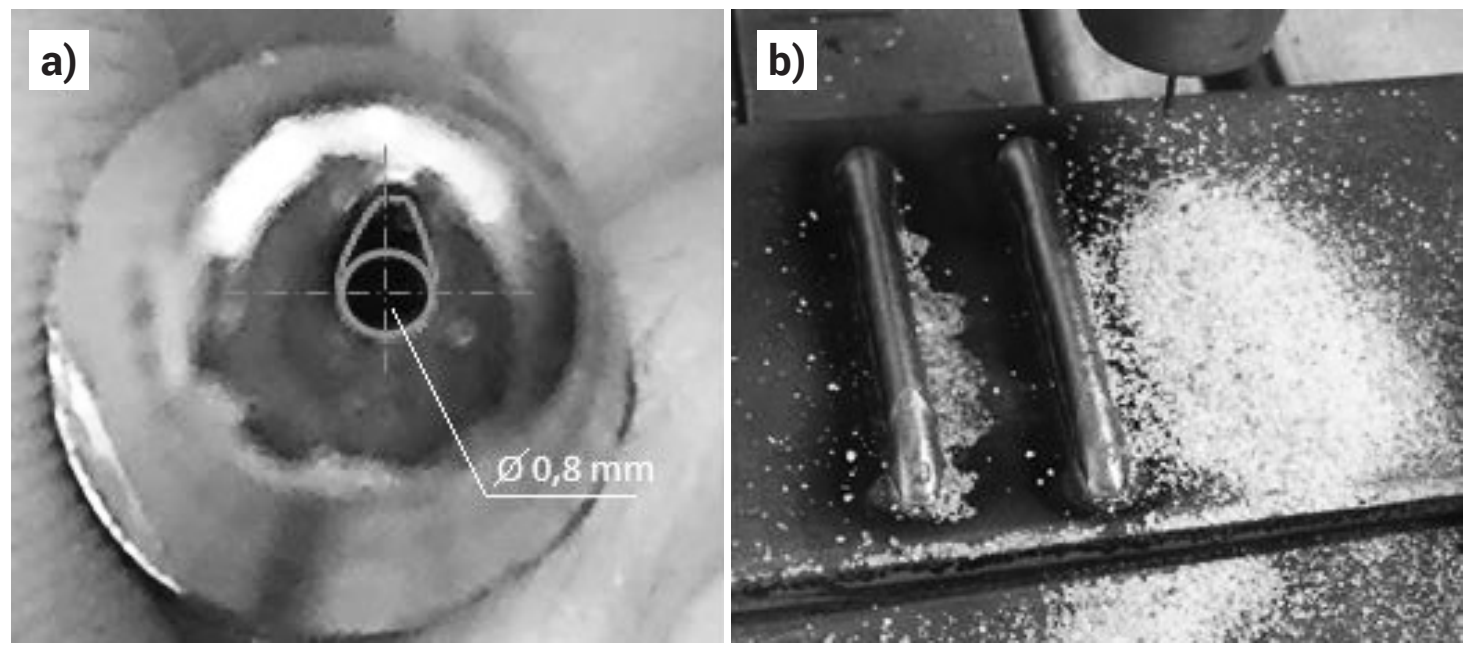

Rys. 3. Modyfikacje próbek i osprzętu: a) zużyta tulejka prądowa, b) próbka pokryta piaskiem

Fig. 3. Modifications of samples and accessories: a) worn contact tube, b) work surface covered with sand 


\section{a)}

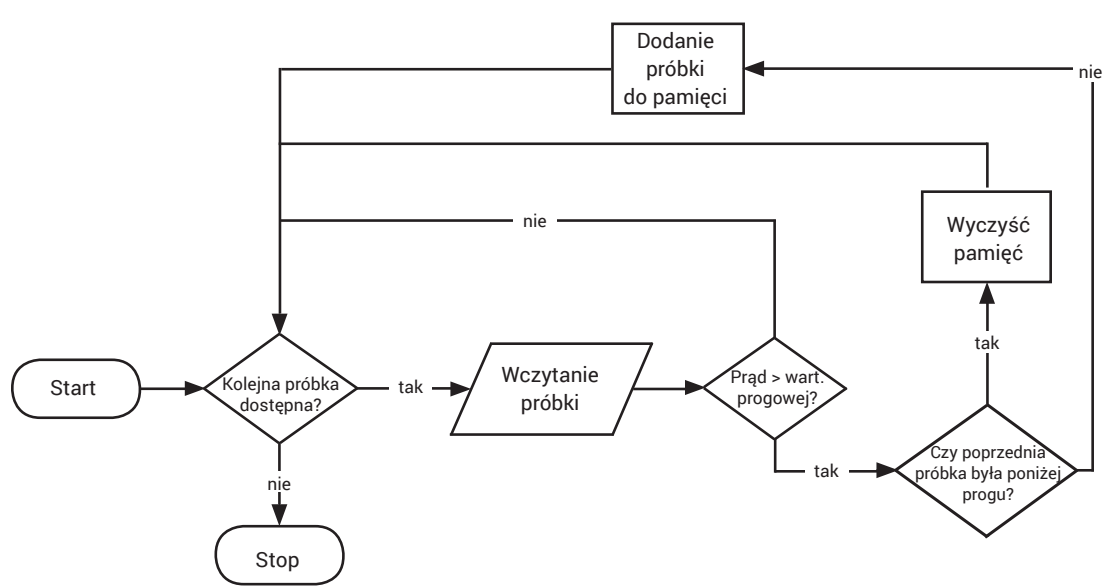

b)



Rys. 5. Usuwanie okresów bezczynności źródła zasilającego łuk: a) algorytm kodu aplikacji LabView, b) przykładowy przebieg prądu spawania przed i po filtrowaniu

Fig. 5. Removing idle periods of the source powering the arc: a) algorithm of LabView code used for filtering, b) sample voltage waveform before and after removal of idle parts

a)

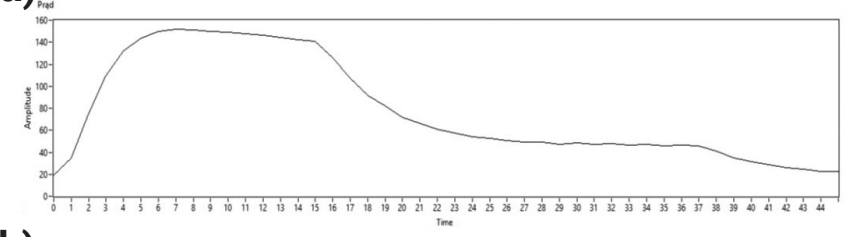

b)

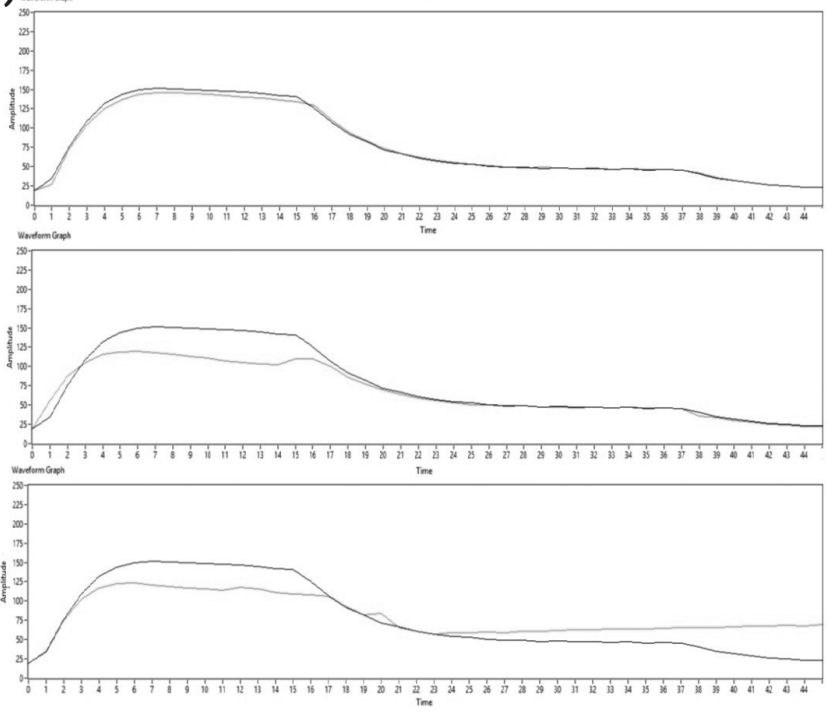

Rys. 6. Przykład analizy impulsów prądowych w procesie MAG Puls: a) impuls wzorcowy, b) efekt nałożenia wzorca na sygnały badane o różnym stopniu odchylenia $(5 \%, 14 \%$ i $25,9 \%)$

Fig. 6. An analysis example of current pulses in MAG Pulse: a) benchmark pulse, b) benchmark pulse overlayed with tested pulses having various distortion factors $(5 \%, 14 \%, 25.9 \%)$ a)

b)
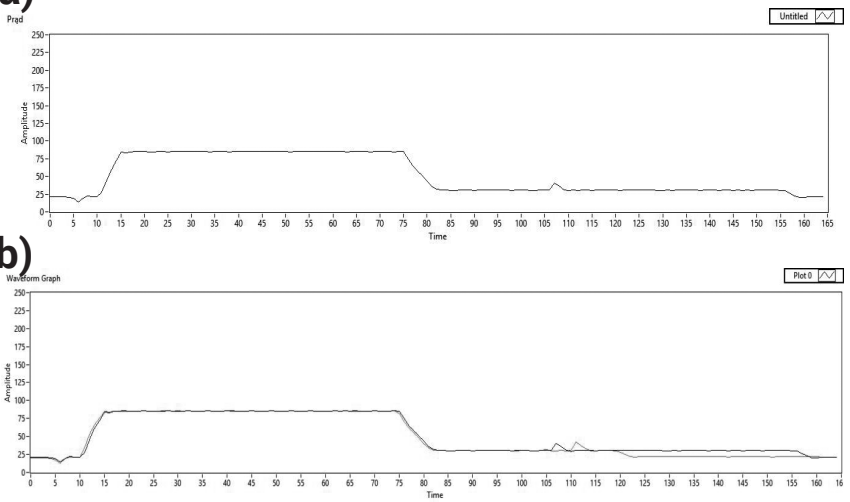

Rys. 7. Przykład analizy impulsów prądowych w procesie CMT a) impuls wzorcowy, b) efekt nałożenia wzorca na sygnał badany o stopniu odchylenia $8 \%$

Fig. 7. An analysis example of current pulses in CMT welding: a) benchmark pulse, b) benchmark pulse overlayed with pulse having $8 \%$ distortion factor

Zadaniem ostatniego bloku programu jest analiza przebiegu współczynnika wychylenia oraz przyporządkowanie przebiegu do jednej z trzech grup: spawanie prawidłowe, zużyta/uszkodzona tuleja prądowa oraz zanik osłony gazowej. Analiza odbywa się dwutorowo i oparta została na dobranych eksperymentalnie progach - na podstawie wyliczonej, średniej wartości współczynnika odchylenia impulsu od wzorca oraz na podstawie najwyższej wartości histogramu procentowego przebiegu współczynnika odchyleń (tabl.1). 
Tablica I. Dobrane eksperymentalnie progi oceny

Table I. Experimentally selected thresholds for automatic evaluation

\begin{tabular}{|c|c|c|}
\hline & $\begin{array}{c}\text { Wartość średnia } \\
\text { odchylenia }\end{array}$ & $\begin{array}{c}\text { Wartość } \\
\text { maksymalna } \\
\text { histogramu }\end{array}$ \\
\hline Spawanie poprawne & $<5 \%$ & $>5 \%$ \\
\hline Zużyta tuleja prądowa & $5 \div 15 \%$ & $2,5 \div 5 \%$ \\
\hline Utrata osłony gazowej & $>15 \%$ & $<2,5 \%$ \\
\hline
\end{tabular}

\section{Prace eksperymentalne}

Poniżej, na rysunkach $8 \div 12$, przedstawiono przykładowe wyniki badań dla odmiany MAG Puls, prezentowane w układzie: widok napoiny, wykres wartości chwilowych współczynnika odkształcenia przedstawiony w dziedzinie czasu, rozkład jego wartości w postaci histogramu oraz odpowiedź uzyskana w warunkach automatycznej oceny.

Napawanie bez wprowadzanych zakłóceń (rys. 8), przy wykorzystaniu wyeksploatowanej miedzianej tulejki prądowej (rys. 9) czy z całkowicie odciętą osłoną gazową (rys. 11) dało jednoznaczną, trafną ocenę systemu w oparciu o dobrane progi oceny, zarówno histogramu, jak i odchylenia średniego. Niekiedy jednak ocena nie była jednoznaczna $z$ uwagi na zbyt małe amplitudy fluktuacji badanych impulsów, np. przy przejściu łuku z metalicznie czystej powierzchni na powierzchnię zanieczyszczoną piaskiem, przy nieznacznie zredukowanej osłonie gazowej (rys.10) lub podczas napawania poprzecznie do uprzednio nałożonych napoin (rys. 12). Dla ostatniego przypadku przebieg współczynnika odchylenia został dodatkowo powiększony (rys. 12), aby ukazać jego zmiany odpowiadające napotykaniu przeszkód. Niestety, ze względu na bardzo niewielką amplitudę tych fluktuacji na obecnym etapie nie udało się zastosować skutecznej metodyki do zidentyfikowania tego rodzaju zakłócenia.
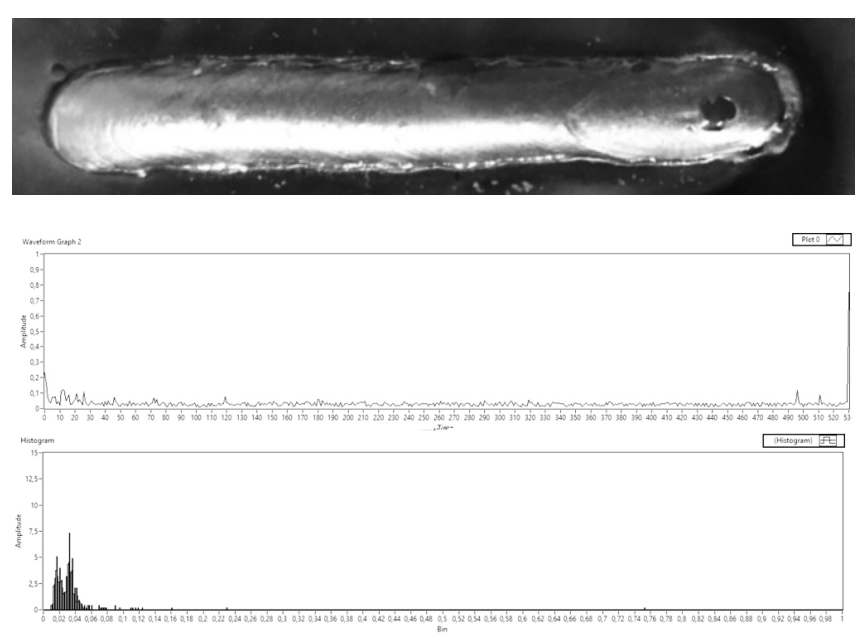

Rys. 8. Napawane bez wprowadzania zakłóceń (MAG Puls), odpowiedź systemu - spawanie poprawne (histogram i odchylenie średnie) Fig. 8. Pad welding without introduced interruptions (MAG Pulse). The system's response: correct weld (based both on histogram and average deviation)

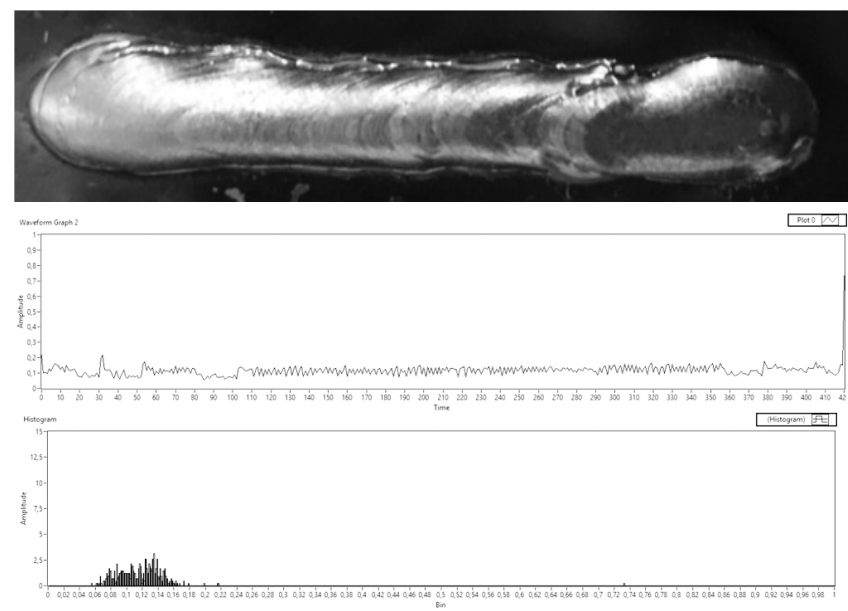

Rys. 9. Napawanie przy wykorzystaniu wyeksploatowanej miedzianej tulejki prądowej (MAG Puls), odpowiedź systemu - zużyta tuleja (histogram i odchylenie średnie)

Fig. 9. Pad welding with worn out copper contact tube (MAG Pulse). The system's response: worn tube (based both on histogram and average deviation)
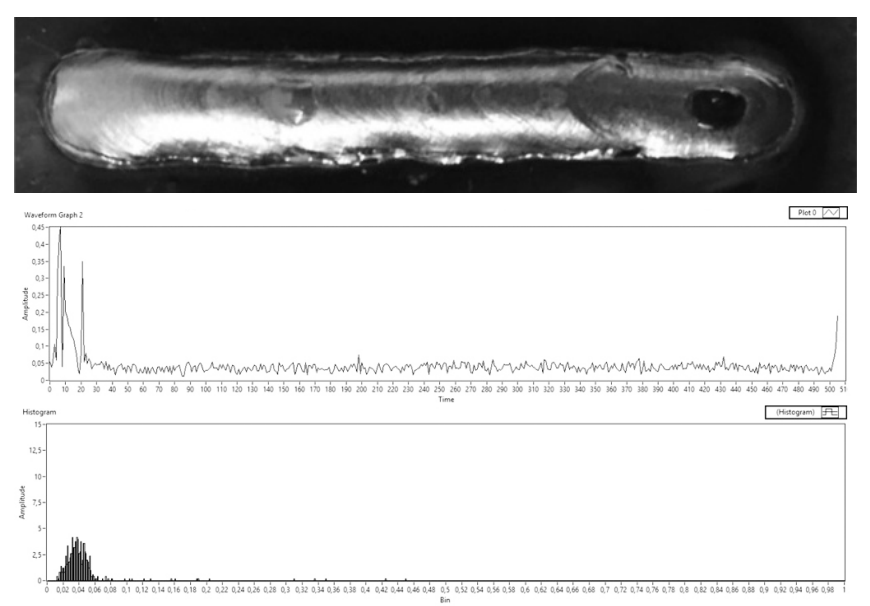

Rys. 10. Napawanie przy zredukowanym (ok. $8 \mathrm{l} / \mathrm{min}$ ) wypływie gazu osłonowego (MAG Puls), odpowiedź systemu - zużyta tuleja (histogram) i spawanie poprawne (odchylenie średnie)

Fig. 10. Pad welding with shielding gas flow reduced to $8 \mathrm{l} / \mathrm{min}$ (MAG Pulse). The system's response: worn contact tube (based on histogram) and correct weld (average deviation)
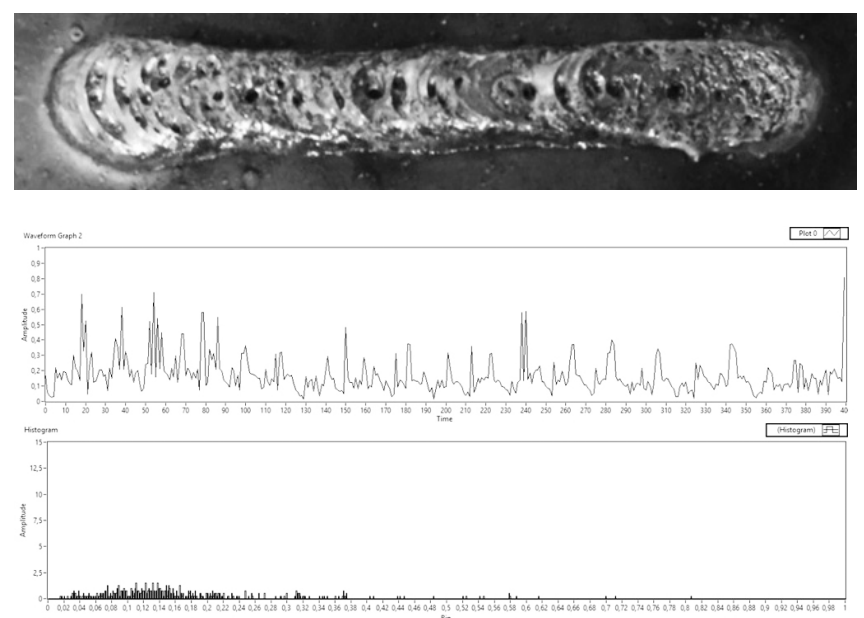

Rys. 11. Napawanie przy odciętym wypływie gazu osłonowego (MAG Puls), odpowiedź systemu - brak gazu (histogram i odchylenie średnie)

Fig. 11. Pad welding without shielding gas (MAG Pulse). The system's response: lack of shielding gas (based on both: histogram and average deviation) 

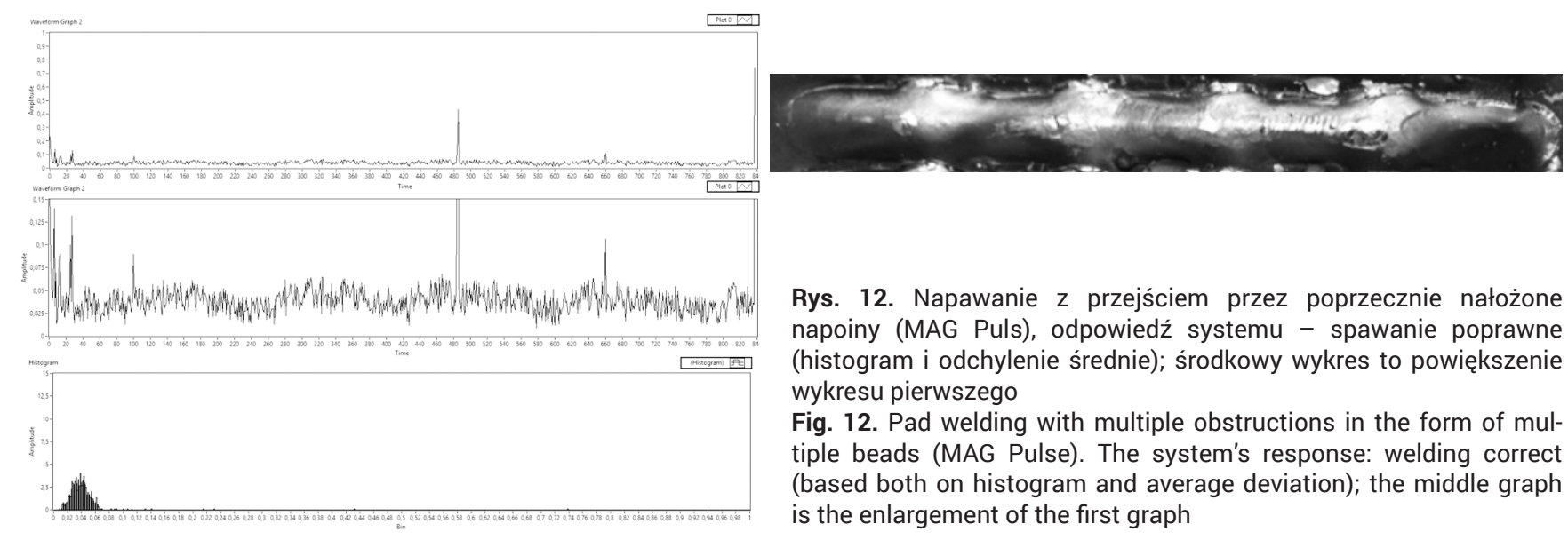

Rys. 12. Napawanie z przejściem przez poprzecznie nałożone napoiny (MAG Puls), odpowiedź systemu - spawanie poprawne (histogram i odchylenie średnie); środkowy wykres to powiększenie wykresu pierwszego

Fig. 12. Pad welding with multiple obstructions in the form of multiple beads (MAG Pulse). The system's response: welding correct (based both on histogram and average deviation); the middle graph is the enlargement of the first graph

\section{Podsumowanie}

Badania potwierdziły częściową przydatność zaprezentowanej metody do bieżącej kontroli i analizy zakłóceń procesu spawania lukowego MIG/MAG w oparciu o wypracowane eksperymentalnie progi oceny (tabl. 1).

Zaobserwowano pewne ograniczenia metody. Zbyt "słabe” bodźce (amplitudy fluktuacji badanych impulsów) skutkują niejednoznaczną odpowiedzią systemu (np. redukcja gazu, rys. 9), a nawet niemożnością zastosowania metody (przejście przez napoiny, rys. 11). W przypadku napawania w poprzek napoin, po powiększeniu przebiegu współczynnika odchylenia kształtu widać falistość tego przebiegu (rys. 11), odzwierciedlającą kolejne bruzdy. W takim wypadku zasadne wydaje się zaprogramowanie kolejnego filtra, wykrywającego tego typu sygnały.

Po przeprowadzeniu większej ilości prób możliwe będzie doprecyzowanie procentowych kryteriów oceny (tabl. 1).

W trakcie dotychczasowych badań nie sprawdzono skuteczności metody podczas równoczesnego symulowania kilku zakłóceń, wydaje się jednak, że w takim przypadku niezbędne będzie wprowadzenie dalszych kryteriów różnicujących.

Pomimo zauważonych ograniczeń periodyczny, impulsowy charakter sygnału prądowo-napięciowego towarzyszącego spawaniu łukowemu elektrodą topliwą daje nadzieję na skuteczne zastosowanie opracowanej metodyki do innych odmian metody MIG/MAG, a także innych procesów. W tym kierunku powinny podążać dalsze badania.

Niewątpliwą zaletą przedstawionej metodyki jest krótki czas automatycznej analizy. Przykładowo, sygnał składający się z ok. 80000 próbek, odpowiadający 8 sekundom spawania, przetwarzany był w ciągu 0,38 s.

\section{Literatura}

[1] Cegielski P.: Pomiary w procesach spawalniczych cz.1, Przegląd Spawalnictwa 7/2016, s. 52-53.

[2] Cegielski P., Kolasa A., Kuczyński M., Rostkowska R.: Wybrane aspekty pomiarów i monitorowania podczas spawania łukowego, Przegląd Spawalnictwa 12/2016, s. 43-50.

[3] Cegielski P., Kolasa A., Sarnowski T., Silbert B.: Koncepcja systemów monitorowania spawalniczych stanowisk zrobotyzowanych, Przegląd Spawalnictwa, 8-10/2002, s. 181-184.

[4] Cegielski P., Kolasa A., Sarnowski T., Silbert B., Michalis A.: System interfejsów sterujących i monitorowania zrobotyzowanego spawania łukowego, Przegląd Spawalnictwa, 5-7/2004, s. 85-88.

[5] Cegielski P., Skrzyniecki K., Kolasa A., Kołodziejczak P.: Badania stabilności układu łuk - urządzenie zasilające $w$ warunkach symulowanych zakłóceń procesu spawania metodą MAG, Przegląd Spawalnictwa 4/2013, s. 18-27.

[6] Huanca Cayo E., Crisostomo S., Alfaro A.: Weld interference detection based on airborne acoustical monitoring of the MIG/MAG process, Welding International 12/2010 pp. 926-933.

[7] Kolasa A., Cegielski P., Skrzyniecki K.: Sprawozdanie merytoryczne z realizacji projektu badawczego własnego N N503 206339/2063/B/ T02/2010/39, Badanie zależności pomiędzy zjawiskami zachodzącymi w łuku spawalniczym w różnych odmianach metody MAG, a parametrami elektrycznymi układu łuk - urządzenie spawalnicze, Politechnika Warszawska 12/2013.

[8] Kurs aktualizacji wiedzy dla Europejskiego Inżyniera Spawalnika. Instytut Spawalnictwa, Gliwice 1998.

[9] Luksa K., Fitrzyk J., Szpakowski E.: Analiza parametrów metodą wykrywania zakłóceń procesu spawani, Przegląd Spawalnictwa 11/2012, s. 29-34. 